\title{
Kebijakan Jarak Ritel Modern dengan Pasar Tradisional Berbasis Sistem Informasi Geografis
}

Modern Ritel Distance Policy with Traditional Market Based on Geographic Information System

\author{
Ayu Pertiwi \\ ${ }^{1}$ Program Studi Teknik Informatika Fakultas Ilmu Komputer Universitas Dian Nuswantoro/ \\ Jln. Imam Bonjol 207 Gd H Semarang, 50131 Jawa Tengah, (024)3575916. \\ ayupertiwi@gmail.com,
}

\begin{abstract}
Abstrak
Kehadiran ritel modern yang berderet di hamper setiap jalan utama kota besar, maupun kota kabupaten sudah menjadi pemandangan yang tidak asing lagi. Masyarakat setempat maupun yang sedang dalam perjalanan sangat terbantu dengan kehadiran ritel tersebut. Ketersediaan barang yang memadai, kualitas barang yang terjaga, harga bersaing, dan kenyamanan tempat akan menjadi pilihan pengujung. Di lain pihak, para pedagang kecil di pasar, maupun pemilik toko domestic (kelontong) merasa terancam ekonominya dengan tumbuh pesatnya pasar ritel modern tersebut. Tidak adanya Perda yang mengatur tentang regulasi jarak antar ritel menjadi salah satu penyebab berdirinya ritel yang saling berdekatan. Penelitian Penentuan variabel faktor lokasi jarak pasar ritel modern dan pasar tradisonal ini, dengan dukungan Metode Agile dan Metode Delphi diharapkan dapat membantu pembuat kebijakan dalam menentukan arah pertumbuhan ekonomi lokal dan pemerataan ekonomi bagi masyarakat sekitar. Metode Delphi digunakan untuk menentukan factor-faktor berdasarkan pendapat pakar atau orang-orang yang mengetahui banyak tentang ritel modern, pengelolan tata ruang, kependudukan, dan perkembangan ekonomi suatu wilayah. Penelitian ini diharapkan dapat mempermudah pembuat kebijakan dalam proses perijinan yang lebih transparan, dan terukur untuk pendirian dan penentuan jarak antara ritel modern dan pasar tradisional maupun toko domestik atau toko kelontong.
\end{abstract}

Kata kunci : Ritel Modern, Agile, Delphi Methode,

\begin{abstract}
Abstrak
The presence of modern retail that lined in almost every major city street, as well as the city district has become a familiar sight. Local people and those on the way are greatly helped by the retail presence. The availability of adequate, the quality of the goods maintained, competitive prices, and the comfort of the place will be the choice. On the other hand, small traders in the market, as well as domestic store owners feel threatened by the rapid growth of modern retail market. The absence of a regulation that regulates the regulation of the distance between retail to be one of the causes of the establishment of an adjacent retail. Research the determination of distance factor variables of modern retail market and traditional market, with support of Agile and Delphi Method is expected to assist policy makers in determining the direction of local economic growth and economic equity for the surrounding community. This research is expected to facilitate policymakers in the process of licensing more transparent, and measurable for the establishment and determination of the distance between modern retail and traditional markets as well as domestic stores or grocery stores.
\end{abstract}

Keywords: Ritel Moder n, Pasar Tradisional, Metode Delphi 


\section{PENDAHULUAN}

Saat ini perkembangan ritel modern sudah sangat tinggi bahkan sudah menjamur di hampir setiap sudut kota dan wilayah pedesaan. Hal ini dapat dilihat dari setiap jalan utama bahkan jalan di perumahan sudah berderet ritel modern. Persaingan antar ritel modern sudah sedemikian tingginya, lokasi ritel modern dan pasar tradisional sudah sangat berdekatan, bahkan antar ritel modern sudah bersebelahan dan berseberang jalan.

Tingkat pertumbuhan ekonomi yang mencapai $6.4 \%$ membuat pasar ritel semakin agresif dan atraktif. Pertumbuhan bisnis ritel kini mencapai $12 \%$. Beberapa gerai beralih fungsi dari supermarket menjadi hypermart, hal ini merupakan salah satu penyebab meningkatnya jumlah ritel modern. Pada tahun 2007 jumlah gerai mencapai 8.889 unit dan saat ini sudah mencapai sekitar 16.000 unit.[1]

Bila dilihat dari tingkat keuntungan, bisnis ini merupakan usaha yang tingkat keuntungannya tidak terlalu tinggi, yaitu sekitar 1.5\%-2\%. Walaupun keuntungan yang didapat tidak tinggi tapi usaha ini memiliki tingkat likuiditas tinggi karena penjualan secara tunai ke konsumen. Data ini didukung oleh penelitian saudara Wyati Saddwisasi, dari jurnal Riptek vol 5 pada tahun 2011, dengan judul “Analisis Dampak Usaha Ritel Modern Terhadap Usaha Ritel Tradisional', dimana penelitian tersebut memaparkan hasil bahwa terjadi penurunan terhadap perputaran pergadangan, bertambahnya jam kerja, dan penurunan jumlah omzet dari penjualan setelah menjamurnya bisnis ritel modern yang terdapat di wilayah Banyumanik, dan Tembalang.[2].

Tulisan ini juga didukung oleh temuan penelitian yang dilakukan oleh Suryadarma, yang menyebutkan bahwa supermarket adalah penyebab tunggal dari kelesuan pasar tradisional. Temuan lain dari hasil analisis membuktikan bahwa pasar tradisional yang berada dekat supermarket berdampak lebih buruk dibandingkan pasar yang lokasinya berjauahan dengan supermarket.[3].

Saat ini di kota Semarang tak kurang dari 100 buah ritel tersebar di berbagai sudut kota. Hal ini sangat meresahkan pedagang tradisional yang sudah dikenal masyarakat sejak jaman dahulu dengan kekhasannya yaitu adanya proses tawar menawar. Dengan adanya kondisi ini diperlukan ketegasan dari pemerintah kota dan kabupaten untuk melakukan pembatasan pemberian ijin usaha. Pemerintah pusat melalui Kementrian Perindustrian dan Perdagangan telah mengeluarkan Peraturan Meteri Perdagangan (Permendag) nomor 53/M-DAG/PER/12/2008 tahun 2008 tentang pedoman penataan dan pembinaan pasar tradisional, pusat perbelanjaan dan toko modern. Sementara itu hanya beberapa kota dan Kabupaten di Jawa Tengah saja yang telah memiliki peraturan daerah (Perda) tentang aturan pembatasan atau pengendalian bisnis retail modern. Untuk kota Semarang sendiri, pembahasan masih sebatas pada Raperda (Rancangan peraturan daerah).

Daerah Banyumanik dan Tembalang saat ini menjadi daerah sasaran perdagangan bahkan pemukiman penduduk. Pertama adalah dengan perpindahan kampus Undip yang awalnya berada di pusat kota dan pindah ke daerah Tembalang, maka aktivitas perekonomian ikut bergerak. Masyarakat secara perlahan tapi pasti akhirnya ikut memilih lokasi pemukiman, membuat usaha ke lokasi tersebut. Dengan perputaran ekonomi yang bergerak cepat tersebut akhirnya dua lokasi ini banyak dilirik para investor untuk membuat usaha di sana. Salah satunya adalah usaha ritel, toko kelontong, dan sebagainya.

Saat ini di Kecamatan Banyumanik dan Tembalang sudah berdiri sekitar 100 pasar ritel modern, dan lebih dari 100 toko kelontong. Hampir di setiap jalan utama bahkan ke jalan sekunder sangat mudah dijumpai ritel-ritel modern yang jarak satu dengan lainnya sangat berdekatan, bahkan bersebelahan dan berseberang jalan. Sedangkan toko kelontong yang hampir 90 persen dimiliki oleh penduduk sekitar mulai banyak yang sepi pengunjung bahkan tutup. Di sisi lain banyaknya ritel modern yang muncul tidak juga membuat ritel modern tersebut ramai di setiap gerainya. Sejalan dengan hasil dari penelitian yang dilakukan oleh R. Sihotang, 2014 
menyebutkan bahwa dalam pembangunan Pasar Modern harus memperhitungkan kondisi sosial ekonomi masyarakat, juga keberadaan Pasar Tradisional yang ada di wilayah yang bersangkutan harus memperhatikan jarak antara ritel modern dan pasar tradisional, sesuai dengan Peraturan Presiden no. 112 Tahun 2007 tentang Penataan dan Pembinaan Pasar Tradisional, Pusat Perbelanjaan, dan Toko Modern. [4]

Pertumbuhan ritel modern yang sangat pesat ini secara tidak langsung mengakibatkan pelaku usaha domestik (toko kelontong, pedagang pasar) satu persatu kolaps. Dengan adanya Peraturan Pemerintah Nomor 112 Tahun 2007 tentang Penataan dan Pembinaan Pasar Tradisional, Pusat Perbelanjaan dan Toko Modern [5], sebetulnya bisa meredam pertumbuhan ritel modern, tetapi PP ini tidak dianggap cukup untuk diimplementasikan. Selain itu, sesuai dengan pasal yang sama pasal 5 menyebutkan bahwa perkulakan hanya boleh berlokasi pada atau akses system jaringan jalan arteria atau jalan kolektor. Untuk melengkapi PP ini tentunya ada Peraturan Daerah yang mengaturnya untuk masing-masing daerah. Tetapi sayangnya perda yang mengatur tentang jarak lokasi antar satu dengan yang lain belum tercantum di dalam perda yang ada. [6]

Teknik Delphi, yang terutama dikembangkan oleh Dalkey dan Helmer (1963), adalah metode yang banyak digunakan dan diterima untuk mencapai konvergensi pendapat mengenai pengetahuan dunia nyata yang diminta oleh para ahli di bidang topik tertentu. Berdasarkan alasan bahwa, "dua kepala lebih baik dari satu, atau ... n kepala lebih baik dari satu". Teknik Delphi dirancang sebagai proses komunikasi kelompok yang relative terstruktur dengan kuat, dimana hal-hal yang secara alami tidak pasti dan pengetahuan tidak lengkap tersedia, dinilai oleh para ahli, untuk melakukan pemeriksaan dan diskusi terperinci mengenai isu spesifik dengan tujuan penetapan tujuan, penyelidikan kebijakan, atau memprediksi kejadian masa depan. teknik Delphi ini mencoba untuk mengatasi "apa yang seharusnya dilakukan".[7] Dalam penelitian ini metode Delphi dalam pengumpulan pendapat para ahli terutama untuk kriteria yang belum ada atau belum disusun dalam penguatan untuk sebuah kebijakan yang akan menjadi sebuah usulan dalam pembuatan peraturan daerah tentang jarak lokasi antar satu ritel dengan ritel lainnya.

Dari permasalahan di atas maka perlu dikaji tentang jarak lokasi ritel modern dengan pasar tradisional maupun antar ritel modern sendiri yang ideal untuk sebuah kota/ kabupaten. Kajian lainnya adalah apakah keberadaan ritel-ritel modern yang jaraknya belum diatur oleh perda berdampak pada perkembangan pasar tradisional. Untuk mendukung penelitian ini digunakan metoda Agile sebagai proses analisis pengembangan perangkat lunak dan sistem informasi geografis untuk ketepatan jarak yang presisi dengan lokasi bumi yang sesungguhnya.

Penelitian ini sangat penting mengingat saat ini banyak pengusaha domestik khususnya yang menjual barang kelontong atau kebutuhan sehari-hari sudah banyak yang kolaps atau bahkan tutup. Hal ini akibat dari tingkat persaingan yang tinggi antar penjual domestik dengan pengusaha ritel modern. Dengan adanya penelitian ini diharapkan menjadi bahan masukan untuk pemerintah yaitu adanya unsur atau faktor baru yang dalam penentuan jarak antar ritel. Dibantu dengan teknologi GIS memudahkan pemerintah dalam mengukur, dan melihat persyaratan yang ditentukan khususnya yang berhubungan dengan jarak, tingkat pendapatan suatu daerah atau wilayah, dan kepadatan penduduknya.

\section{METODE PENELITIAN}

Proses analisis yang dipilih untuk membuat solusi dari permasalahan adalah model Agile Development yang dikombinasikan dengan Metoda Delphi. Proses analisis ini akan membandingkan aturan normatif dengan landasan konsep Agile (literatur dan pakar). Sedangkan metoda Delphi digunakan untuk penentuan faktor-faktor berdasarkan pendapat pakar atau orangorang yang mengetahui banyak tentang Ritel Modern, pengelolaan tata ruang, kependudukan, dan perkembangan ekonomi suatu wilayah. Pakar di sini juga akan melihat efektivitas suatu layanan 
terhadap pelanggan. Diharapkan teknologi GIS dapat membantu proses penentuan lokasi jarak ritel modern dan pasar tradisional.

Langkah selanjutnya adalah melakukan analisis data baik analisis spasial maupun analisis substansial dengan alat analisis sebagai alat bantu untuk menampilkan hasil yang diharapkan. Setelah hasil analisis diinterprestasikan akan didapat temuan-temuan yaitu berupa varibel penentu yang tepat untuk jarak ritel modern dan pasar tradisional.

\section{Pendekatan Analisis dan Metode}

Metode penulisan dalam penelitian ini menggunakan metode deskriptif yang merupakan penelitian yang menuturkan, menganalisis, dan mengklasifikasi dengan berbagai teknik seperti survey, wawancara, observasi, dan angket.

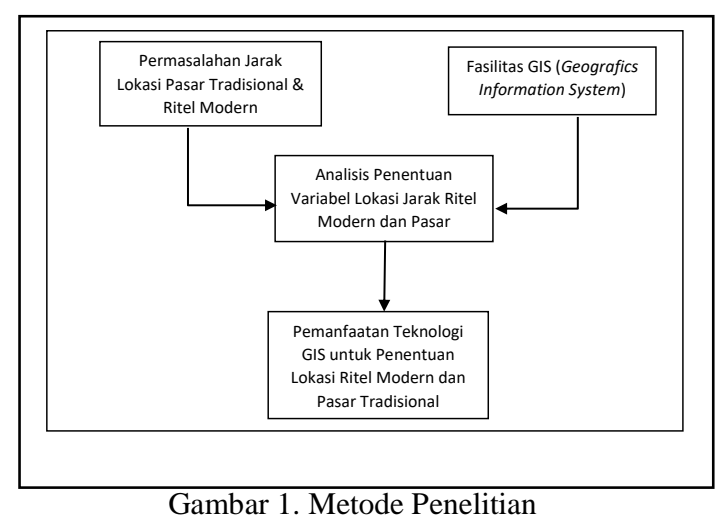

Metode deskriptif dimulai dengan pengumpulan data, penyusunan, uraian, dan analisis. Secara garis besar pendekatan yang dilakukan adalah sebagai berikut :

1. Pendekatan melalui persepsi supplier (penyedia jasa).

Pendekatan melalui persepsi supplier (pedagang maupun pengusaha ritel) melalui karakteristik dari ekspektasi (harapan) dari para penyedia jasa tersebut.

2. Pendekatan melalui persepsi demand (pembeli).

Pendekatan melalui persepsi demand melalui karakteristik dari ekspektasi/ yang diharapkan dari sisi pembeli terhadap supplier. Selanjutnya dalam melakukan proses pembangunan sistem penentuan jarak lokasi ritel dan pasar tradisional menggunakan metode Agile development[8]. Dimana metode tersebut sangat baik untuk sebuah sistem yang mengharuskan bisa terus melakukan komunikasi dengan usernya, dan dilakukan secara continues improvement akan menghasilkan produk secara berkala. Untuk dapat berkomunikasi dengan baik dan untuk mendapatkan informasi mengenai faktor-faktor penentuan jarak lokasi dari pakar dibutuhkan sebuah metode lain yaitu Metode Delphi.

Tahapan yang dilakukan dalam penelitian ini adalah : 


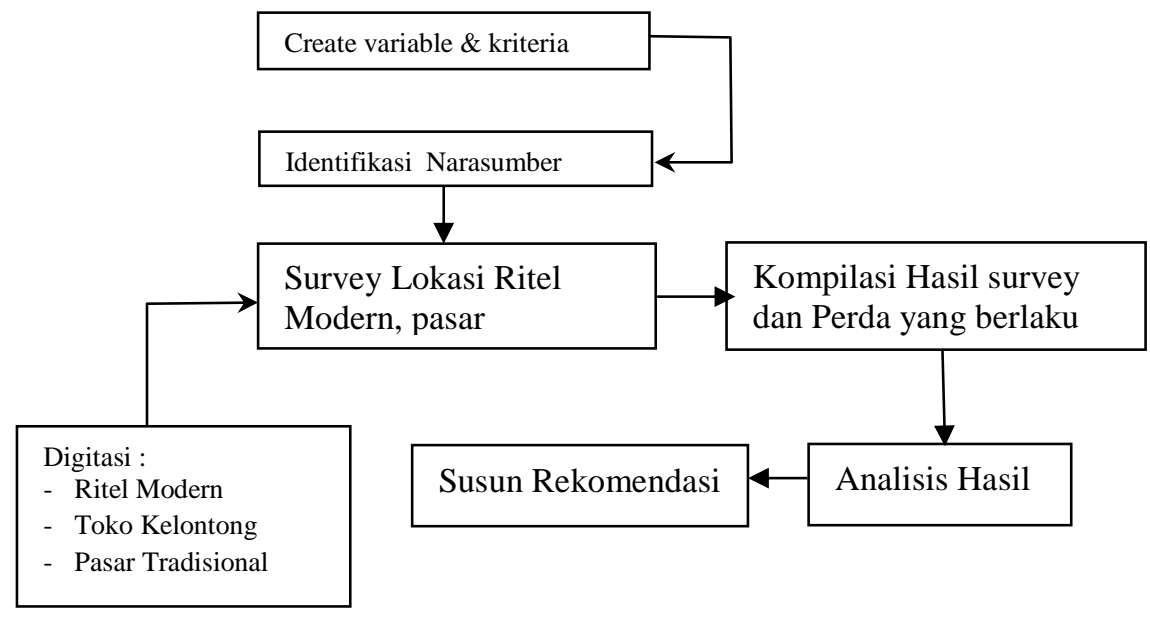

Gambar 2. Tahapan Penelitian

Kebutuhan Data

Data primer dalam penelitian ini merupakan data yang diperoleh secara langsung dari sumber dengan cara mendigitasi langsung titik/ lokasi yang dijadikan objek penelitian, dan data-data yang ditanyakan secara langsung kepada pemilik toko maupun ritel. Data-data yang ditanyakan berkaitan dengan sasaran penelitian, yaitu mengidentifikasi setiap faktor yang dipertimbangkan dalam rangka menganalisis faktor-faktor penentu jarak lokasi ritel modern dan pasar tradisional di Kecamatan Banyumanik dan Tembalang Kota Semarang.

Proses digitasi lokasi dilakukan terhadap lokasi ritel modern yang tersebar di Kecamatan Banyumanik dan kecamatan Tembalang, yang terdiri dari Lokasi Ritel Modern, yaitu Indomaret, Alfamart, Superindo, Hypermart:

1. Lokasi Pasar Tradisional

2. Toko Kelontong, yaitu toko yang menyediakan barang-barang kebutuhan sehari-hari.

Data sekunder dalam penelitian ini merupakan data yang diperoleh dari sumber lain, yaitu dengan menyalin dalam bentuk informasi yang sudah jadi. Data sekunder tersebut diperoleh dari referensi dan informasi data digital yang berasal dari internet.

\section{Teknik pengumpulan data yang digunakan adalah sebagai berikut :}

Wawancara langsung dengan menggunakan kuesioner yang diajukan kepada responden. Pertanyaannya bersifat terbuka, yang dapat dijawab secara bebas oleh responden.

1. Observasi atau pengamatan langsung di lapangan untuk mendapatkan informasi lokasi berupa koordinat $(\mathrm{x}, \mathrm{y})$ dengan menggunakan proses digitasi.

2. Studi Literatur

3. Dokumentasi, yaitu teknik yang digunakan untuk mendapatkan data sekunder dengan mempelajari arsip atau data yang ada kaitannya dengan objek penelitian.

\section{Teknik Pengolahan/ Kompilasi dan Penyajian Data}

Data primer yang telah dikumpulkan dari hasil observasi dan wawancara maupun pengamatan yang dilakukan masih berupa data mentah, sehingga diperlukan proses pengolahan dan penyajian 
sehingga data dapat dianalisis. Tahap-tahap pengolahan dan penyajian yang dilakukan adalah sebagai berikut :

1. Proses pemeriksaan data yang masuk secara manual.

2. Input, kegiatan memasukkan data manual menjadi data digital.

3. Klasifikasi Kode, proses pengelompokan data yang sejenis, dan termasuk pemberian kode untuk setiap data yang masuk.

4. Calculating, proses perhitungan data berdasarkan jarak yang ada berdasarkan kondisi real di lapangan.

\section{HASIL DAN PEMBAHASAN}

Standar Nasional Indonesia (SNI) 03-6981- tahun 2004 tentang Tata cara perencanaan lingkungan perumahan sederhana tidak bersusun di daerah perkotaan, dijelaskan bahwa penyediaan fasilitas niaga di kawasan permukiman yang berkaitan dengan jenis fasilitas yang disediakan telah diatur baik untuk jumlah minimum penghuni yang dilayani, letak, jarak, dan luas lahan yang dibutuhkan.[9] Berdasarkan aturan tersebut maka jumlah penduduk Kecamatan Banyumanik 143.518 ( 71.993 orang pria, dan 71.525 wanita, dan Kecamatan Tembalang 169.771 ( 85.145 orang pria, 84.626 orang wanita).

Tabel 1. Fasilitas Niaga pada Kawasan Permukiman

\begin{tabular}{|c|c|c|c|c|c|c|}
\hline No. & $\begin{array}{l}\text { Fasilitas yang } \\
\text { disediakan }\end{array}$ & $\begin{array}{l}\text { Jumlah Minimun } \\
\text { penghuni yang } \\
\text { dillayani (fiwa) }\end{array}$ & Fungsi & $\begin{array}{l}\text { Letak dan jarak } \\
\text { maksimum dari unit } \\
\text { hunian }\end{array}$ & $\begin{array}{l}\text { Luas lantai } \\
\text { minimum (m2) }\end{array}$ & $\begin{array}{c}\text { Luas lahan minimum } \\
(\mathrm{m} 2)\end{array}$ \\
\hline & Warung & 250 & Menjual sembilan ké- & 1. Terletak di pusat ling- & 50 & 100 \\
\hline & & & butuhan pokok & kungan & (termasuk gudang) & (tidak bersatu dengan \\
\hline & & & & 2. Mudah dicapai & & frumah) \\
\hline & & & & $\begin{array}{l}\text { 3. Radius pencapaian } \\
\text { maksimum } 500 \text { meter }\end{array}$ & & \\
\hline & Pertókoan P \& D & 2,500 & Menjual barang kébu= & 1. Terletak di pusat ling- & 480 & 1,200 \\
\hline & & & tuhan sehari-hari ter- & kungan & & (KDB 40\%) \\
\hline & & & masuk sandang dan & 2. Radius pencapaian & & \\
\hline & & & pangan & maksimum 500 meter & & \\
\hline & Pusat Peibelañjaân & 2,500 & Menjual barang kebu- & 1. Terletak pada jalan & & 13,500 \\
\hline & Lingkungan & & tuhan sehari-hari ter- & utama lingkungan & & $(0.9=1 \%$ dari luas \\
\hline & & & masuk sayur, daging. & 2. Terletak di pusat & & areal permukiman \\
\hline & & & ikan, buah-buahan, & lingkungan & & yang dilayani) \\
\hline & & & beras, sandang, alat- & & & \\
\hline & & & alát pendidikan, rumăh & & & \\
\hline & & & tangga. Berupa pasar & & & \\
\hline & & & dan toko-toko lengkap & & +2 & \\
\hline & & & dengan parkir umum & & 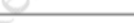 & \\
\hline & & & & & & \\
\hline & & & & & & \\
\hline
\end{tabular}

Berdasarkan Tata cara perencanaan lingkungan perumahan sederhana, SNI maka banyaknya warung, toko P\&D, dan Pusat Perbelanjaan yang diijinkan di kecamatan Banyumanik mau kecamatan Tembalang adalah sebagai berikut :

Tabel 2. Analisis Jumlah warung/toko yang disarankan berdasarkan SNI 03-6981

\begin{tabular}{|l|l|c|c|c|c|c|c|c|}
\hline No & Kecamatan & $\begin{array}{c}\text { Jml } \\
\text { penduduk }\end{array}$ & $\begin{array}{c}\text { Jml } \\
\text { warung }\end{array}$ & $\begin{array}{c}\text { Jml } \\
\text { survey }\end{array}$ & $\begin{array}{c}\text { Jml } \\
\text { toko } \\
\text { P\&D }\end{array}$ & $\begin{array}{c}\text { Jml ritel } \\
\text { survey }\end{array}$ & $\begin{array}{c}\text { Jml Pusat } \\
\text { Perbelanjaan }\end{array}$ & $\begin{array}{c}\text { Jml } \\
\text { P.Perbelanjaan } \\
\text { Survey }\end{array}$ \\
\hline$(1)$ & $(2)$ & $(3)$ & $(4)$ & $(5)$ & $(6)$ & $(7)$ & $(8)$ & $(9)$ \\
\hline 1 & Banyumanik & 143.518 & 574 & 24 & 57 & 19 & 57 & 2 \\
\hline 2 & Tembalang & 169.771 & 679 & 11 & 68 & 27 & 68 & 1 \\
\hline & Jumlah & 313.289 & 1254 & 35 & 125 & 46 & 125 & 3 \\
\hline
\end{tabular}

Maka secara jumlah ritel/ toko yang ada masih memenuhi syarat keberadaannya, bahkan masih kurang bila dibandingkan dengan jumlah penduduk yang ada. Sayangnya SNI tersebut hanya berdasarkan pada jumlah penduduk, tidak melihat kriteria/ variable lainnya seperti jarak, 
kepadatan penduduk, tingkat persaingan antar ritel, tingkat ekonomi, lokasi yang memadai. Untuk itu masih diperlukan analisis kriteria seperti hal di bawah ini :

\section{Analisis Kriteria Lokasi Ritel berdasarkan Persepsi Pembeli.}

Berdasarkan hasil survey wawancara dan studi literatur terhadap pembeli, yaitu didapat informasi bahwa yang dibutuhkan pembeli dalam mendapatkan pelayanan adalah :

Tabel 3. Kriteria Lokasi Ritel Berdasarkan Persepsi Pembeli
\begin{tabular}{|l|l|}
\hline No & \multicolumn{1}{c|}{ Kriteria Ritel/ Pasar Ideal } \\
\hline$(1)$ & \multicolumn{1}{c|}{$(2)$} \\
\hline 1. & Kelengkapan Barang \\
\hline 2. & Kenyamanan Tempat Belanja \\
\hline 3. & Harga, diskon \\
\hline 4. & Jarak lokasi rumah/ kantor \\
\hline
\end{tabular}

\section{Analisis Kriteria Lokasi Ritel Berdasarkan Persepsi Pemilik Ritel/ Toko Kelontong}

Perbedaan persepsi antara pembeli (demand) dan pengusaha ritel/ pedagang dapat dilihat dari tabel di bawah ini, pengusaha akan melihat dari sisi semakin dekatnya jarak ritel yang satu dengan ritel yang lain akan membawa dampak persaingan yang semakin tinggi. Sehingga tingkat kedatangan pembeli tidak tinggi. Jarang terlihat ritel modern (Indomaret, Alfamart) pembelinya saling berdesakan. Berbeda dengan ritel modern, pasar tradisional masih tetap selalu ramai, mengapa demikian? Pasar tradisional menyediakan selain menjual barang kebutuhan pokok, juga menjual barang segar (sayur, buah, ikan, daging, dan lain-lain). Hal ini yang tidak dimiliki oleh ritel modern seperti (Indomaret, Alfamart). Tetapi barang kebutuhan pokok keringnya, dalam arti barang yang sama yaitu yang ada di ritel modern, tidak seramai penjualan barang segar (fresh). Artinya pembeli memiliki kecenderungan membeli barang-barang tersebut di ritel modern, dengan alasan kenyamanan, berat bila sekaligus membawa barang tersebut.

\section{Analisis Kriteria Lokasi Ritel Berdasarkan Persepsi Pemilik Ritel/ toko}

Tabel 4. Kriteria Lokasi Berdasarkan Persepsi Pemilik

\begin{tabular}{|l|l|}
\hline No & \multicolumn{1}{|c|}{ Kriteria Ritel/ Pasar Ideal } \\
\hline$(1)$ & \multicolumn{1}{|c|}{$(2)$} \\
\hline 1. & Kepadatan Penduduk \\
\hline 2. & Tingkat Persaingan yang tinggi \\
\hline 3. & Tingkat Ekonomi \\
\hline 4. & Lokasi memadai \\
\hline 5 & Jenis barang yang dijual \\
\hline
\end{tabular}

Untuk hasil analisis berdasarkan persepsi pemilik ritel/ took bahwa kepadatan penduduk, tingkat persaingan, tingkat ekonomi, lokasi, dan ketersediaan barang yang menjadi kriteria lokasi penempatan ritel modern.

\section{Analisis Kriteria Lokasi Ritel Berdasarkan Persepsi Pemerintah}

Analisis yang telah dilakukan untuk mendapatkan kriteria lokasi ritel yang ideal adalah dengan mengutip pandangan ahli di bidangnya melalui studi literatur dari media berkala Komisi Pengawas Persaingan Usaha yaitu 'Kompetisi' edisi 34 tahun 2012 
Hasil Akhir dari proses ini adalah setelah dilakukan penyaringan kriteria dominan dilakukan proses penggabungan antara kriteria akhir Pakar dengan pelanggan (Customer) dan pemilik (Owner), maka didapat hasil seperti pada tabel di bawah ini :

Tabel 5. Hasil Saringan Kriteria antara P(Pakar, Cu(Customer), dan Ow (Owne $)$
\begin{tabular}{|c|l|c|c|c|c|c|c|}
\hline No & \multicolumn{1}{|c|}{ Kriteria Ritel } & P1 & P2 & P4 & P5 & Cu & Ow \\
\hline$(1)$ & \multicolumn{1}{|c|}{$(2)$} & $(3)$ & $(4)$ & $(5)$ & $(6)$ & $(7)$ & $(8)$ \\
\hline 1 & Aturan Zonasi & $\sqrt{ }$ & $\sqrt{ }$ & $\sqrt{ }$ & $\sqrt{ }$ & $\sqrt{ }$ & \\
\hline 2 & Aturan Jarak & $\sqrt{ }$ & $\sqrt{ }$ & & $\sqrt{ }$ & $\sqrt{ }$ & \\
\hline 3 & Aturan Jam buka ritel modern & $\sqrt{ }$ & $\sqrt{ }$ & & $\sqrt{ }$ & $\sqrt{ }$ & \\
\hline 4 & Kenyamanan & & & & & $\sqrt{ }$ & $\sqrt{ }$ \\
\hline 5 & Kepadatan Penduduk & & & & & & $\sqrt{ }$ \\
\hline 6 & Tingkat Perekonomian & & & & & & $\sqrt{ }$ \\
\hline 7 & Lokasi Strategis & & & & & & $\sqrt{ }$ \\
\hline 8 & Harga & & & & & $\sqrt{ }$ & $\sqrt{ }$ \\
\hline
\end{tabular}

Hasil analisis kriteria di atas akan dievaluasi oleh Pakar dengan menggunakan Metoda Delphi dengan sedikitnya 2 tahap. Setelah pakar mengevaluasi maka akan didapat bobot untuk faktorfaktor penentu jarak ritel modern dan pasar tradisional. Bobot yang telah diberikan oleh pakar akan direkap oleh peneliti, dan hasilnya diserahkan lagi kepada pakar untuk dievaluasi kembali. Apakah hasilnya akan diubah atau akan tetap konsistensi. Hasil inilah yang akan menjadi faktor penentu jarak antar ritel dan pasar tradisonal.

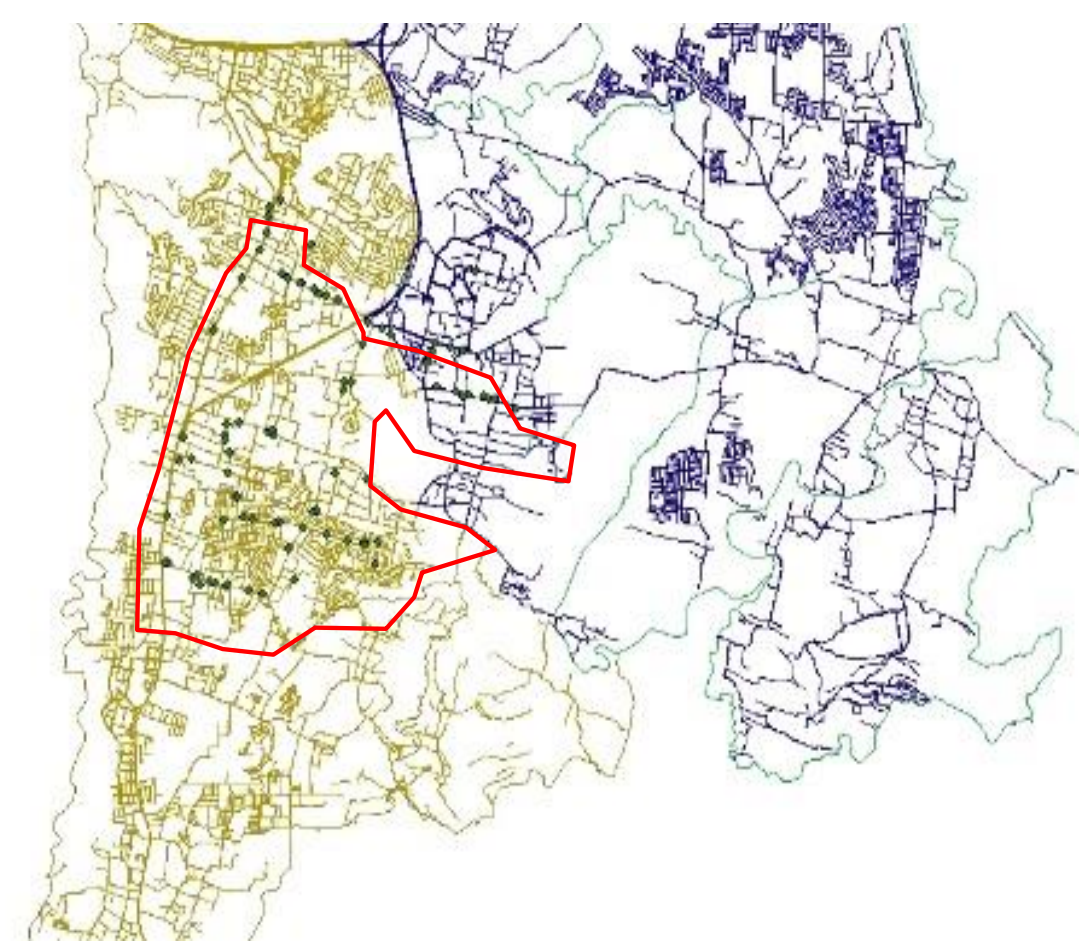

Gambar 2. Peta Sebaran Lokasi Pengamatan di Kec. Banyumanik-Tembalang

Hasil digitasi memperlihatkan bahwa sebaran pasar ritel mengumpul di lokasi-lokasi tertentu yang padat penduduk yaitu di seputar Kecamatan Banyumanik, dan sebagian kecil berada di Kecamatan Tembalang. Sebaran lokasi ritel masih belum sesuai dengan ketentuan maupun melihat padangan pakar. Untuk aturan zonasi, jarak, dan jam buka ritel modern belum dipatuhi pemilik ritel. Tidak semua ritel modern mengikuti aturan jam operasi, ( ada yang beroperasi 24 jam sehari). Untuk kenyamanan sudah sesuai harapan customer, dan hal ini tidak dipermasalahkan 
oleh pakar, Karena memang sudah menjadi keharusan ritel modern memberikan kenyamanan yang lebih dibandingkan pasar tradisional.

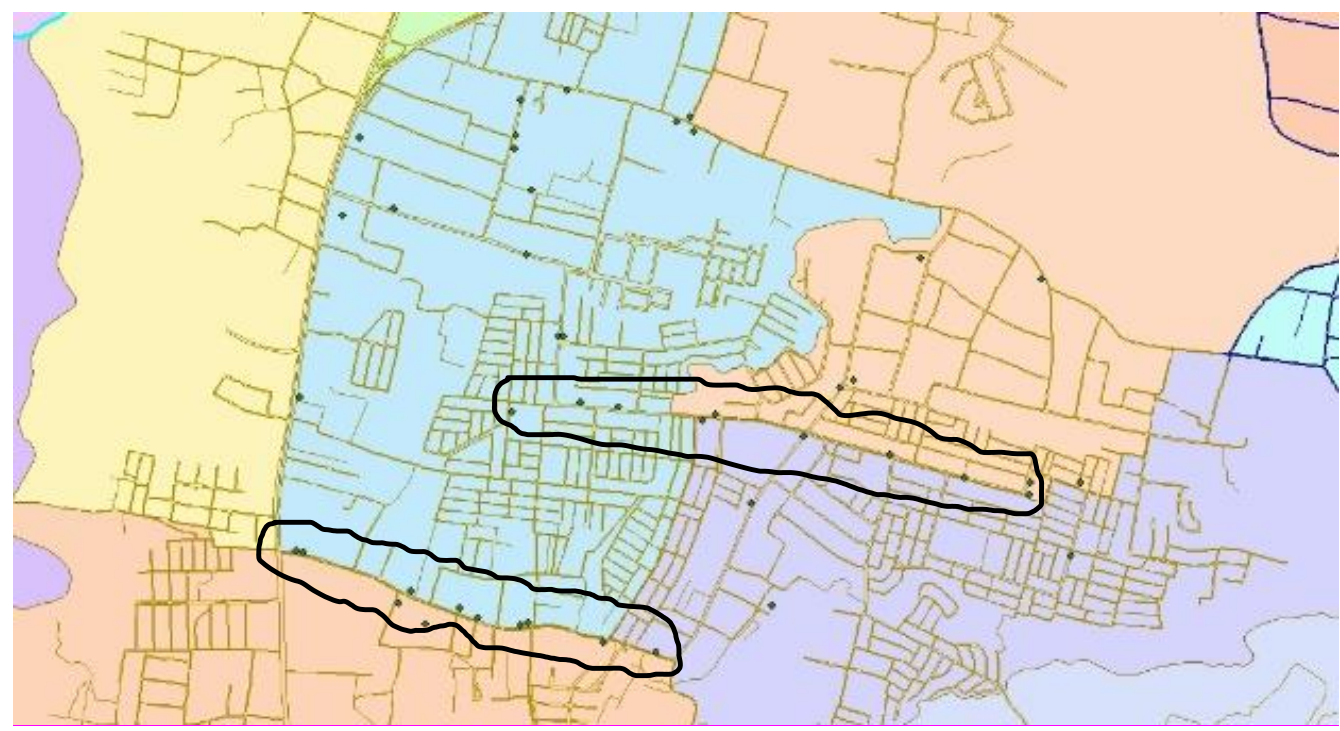

Gambar 3. Peta Loksi Sebaran Ritel Modern dan Pasar Tradisional di Kecamatan Banyumanik-Tembalang

Jelas terlihat pada gambar 3 bahwa lokasi ritel modern dalam satu jalur/ jalan bisa lebih dari 5, bahkan 8 ritel, tepatnya di sepanjang jalan utama Banyumanik, dan jalan utama daerah Tembalang.

\section{KESIMPULAN}

Pertumbuhan ekonomi kerakyatan perlu didukung oleh berbagai pihak, tidak hanya oleh pemerintah saja tetapi juga oleh masyarakatnya dan pelaku usaha itu sendiri. Efektivitas sebuah usaha tidak hanya dilihat dari keuntungan demand/ pembeli saja, tetapi juga semua pihak yaitu pengusaha ritel modern, pasar tradisonal maupun toko kelontong itu sendiri agar ekonomi kerakyatan tidak saling mematikan. Perlu segera dibuatkan sebuah regulasi tentang ijin pendirian ritel modern dengan mempertimbangkan kriteria-kriteria yang telah disusun, juga berdasarkan pada pertimbangan pakar di bidangnya.

Perlunya sebuah metode yang dapat mendukung penuh untuk hasil yang lebih baik. Pemilihan metode Agile dalam pengembangan perangkat lunak ini belum dapat menghasilkan hasil yang maksimal, mengingat bahwa kajian ini banyak melibatkan stakeholder atau ahli. Metode Delphi pada kajian ini berperan dominan, dimana perannya adalah sebagai penguatan dalam mengkaji pendapat para pakar. Metode Delphi merupakan pelengkap metode Agile untuk memberikan informasi yang berfokus pada kajian pakar. Sehingga hasil yang didapat menjadi lebih baik dan akurat.

Teknologi GIS dapat menjadi alat bantu untuk menampilkan informasi-informasi, atribut-atribut lokasi secara transparant, cepat, presisi untuk bahan kajian lokasi pasar ritem modern dan pasar tradisional.

Latar belakang dan kepentingan yang berbeda dari pakar tentunya berdampak pada penentuan kriteria yang ideal dalam penentuan variabel-variabel yang mempengaruhi pendirian sebuah ritel modern, yang diharapkan dapat berjalan seiring dengan keberadaan pasar tradisonal yang menjadi tumpuan ekonomi rakyat. Untuk itu diperlukan sebuah cara yang lebih efektif agar pengerucutan variabel menjadi akurat sesuai dengan kriteria yang dibutuhkan di lapangan sebenarnya. 


\section{SARAN}

Perlu segera disusun regulasi tentang ijin pendirian ritel modern, agar perekonomian rakyat khususnya berkaitan dengan pasar tradisional tidak tergeser.

Aplikasi yang dihasilkan belum memberikan informasi yang detil tentang lokasi digital secara presisi. Ada baiknya penelitian ke depan sudah mengintegrasikan GPS (Global Positioning System) sehingga menjadi lebih interaktif dalam bentuk peta digital, masih berupa titik-titik. Informasi masih dalam bentuk yang sama, sebaiknya penelitian ke depan informasi peta digital sudah dapat memberikan informasi yang informative dan mudah dibaca oleh masyarakat awam.

\section{UCAPAN TERIMA KASIH}

Penulis mengucapkan terima kasih kepada DIKTI yang telah memberi dukungan financial terhadap penelitian pemula untuk tahun anggaran 2014-2015 ini, dan juga kepada Fakultas Ilmu Komputer Universitas Dian Nuswantoro yang telah memberikan kesempatan untuk dapat menyelesaikan penelitian ini.

\section{DAFTAR PUSTAKA}

[1] Dinas Perindustrian dan Perdagangan Prov. Jateng, "Merebaknya pasar ritel di jawa tengah," no. 4, 2013.

[2] S. Wyati, "USAHA RITEL TRADISIONAL," Riptek, vol. 5, no. I, pp. 31-43, 2011.

[3] D. Suryadarma, A. Poesoro, S. Budiyati, Akhmadi, and M. Rosfadhila, Dampak Supermarket terhadap Pasar dan Pedagang Ritel Tradisional di Daerah Perkotaan di Indonesia. Jakarta: Lembaga Penelitian SMERU, 2007.

[4] R. Sihotang and S. Afifuddin, "PENGARUH PASAR MODEREN TERHADAP PEDAGANG PASAR TRADISIONAL DAN MASYARAKAT DALAM PENGEMBANGAN WILAYAH DI KECAMATAN MEDAN AREA," J. Ekon., vol. 17, no. 4, pp. 181-194, 2014.

[5] Presidential Regulation no 112, "Presidential Regulation no 112," p. 112, 2007.

[6] A. Noor, "Perlindungan Di Tengah Ekspansi Pasar Ritel Modern," Economica, vol. IV, no. 2, pp. 107-120, 2013.

[7] C. Hsu and B. Sandford, "The delphi technique: making sense of consensus," Pract. Assessment, Res. Eval., vol. 12, no. 10, pp. 1-8, 2007.

[8] I. Sommerville, Ninth Edition, Ninth. Addison-Wesley Boston, 2010.

[9] S. N. Indonesia and B. S. Nasional, "Tata cara perencanaan lingkungan perumahan sederhana tidak bersusun di daerah perkotaan," 2004. 